\title{
VIII. KRONIKA
}

\section{KONFERENCJA NAUKOWA: „PROFESOR JAN BASZKIEWICZ - CZLOWIEK UNIWERSYTETU”}

Dnia 7 listopada 2011 r. odbyła się zorganizowana przez Instytut Nauk Politycznych Wydziału Dziennikarstwa i Nauk Politycznych Uniwersytetu Warszawskiego, pod patronatem JM Rektor UW prof. dr hab. Katarzyny Macukow-Chałasińskiej, konferencja naukowa Jan Baszkiewicz - czlowiek Uniwersytetu. Konferencja była aktem uczczenia pamięci Jana Baszkiewicza. W wypełnionej Sali Senatu w Pałacu Kazimierzowskim zgromadzili się przedstawiciele świata nauki, prawnicy, historycy, reprezentanci nauk o polityce, by dokonać wstępnego omówienia dzieła życia znakomitego, zmarłego w styczniu 2011 r. uczonego humanisty, a w szczególności odpowiedzieć na pytanie, jakie znaczenie ma Jego twórczość dziś, w latach postępującego kryzysu uniwersytetu.

Konferencję otworzył dyrektor Instytutu Nauk Politycznych UW - prof. dr hab. Stanisław Sulowski, przemówienia powitalne wygłosili prorektor UW - prof. dr hab. Włodzimierz Lengauer i dziekan Wydziału Dziennikarstwa i Nauk Politycznych UW - prof. dr hab. Janusz Adamowski.

W pierwszej części konferencji, zatytułowanej Profesor Jan Baszkiewicz - wielki humanista i czlowiek uniwersytetu, której moderatorem był prof. Janusz Adamowski, wypowiadali się przedstawiciele ośrodków naukowych, $\mathrm{z}$ którymi Jan Baszkiewicz był związany: profesorowie Ewa Eętowska (Polska Akademia Nauk), Michał Pietrzak (Uniwersytetu Warszawski), Wojciech Kaute (Uniwersytet Śląski), Tadeusz Mołdawa (Uniwersytet Warszawski) oraz reprezentanci uniwersytetów, które nadały Mu godność doktora honoris causa: profesorowie Krzysztof Pałecki (Uniwersytet Jagielloński), Teresa Łoś-Nowak (Uniwersytet Wrocławski), Edward Olszewski (Uniwersytet Marii Curie-Skłodowskiej), Michal Śliwa (Uniwersytet Pedagogiczny w Krakowie).W drugiej części konferencji, poświęconej kontynuacji dzieła Profesora w dobie kryzysu uniwersytetów, której moderatorem był prof. Stanisław Sulowski, zabrali głos profesorowie Stanisław Filipowicz (Polska Akademia Nauk), Andrzej Antoszewski (Uniwersytet Wrocławski), Leszek Kubicki (Polska Akademia Nauk), Henryk Olszewski (Szkoła Wyższa Psychologii Społecznej w Warszawie), Krzysztof Pieliński (Uniwersytet Śląski) oraz Tomasz Żyro (Uniwersytet Warszawski).

W części artystycznej Elżbieta Karaś-Kasztel wykonała utwory Ignacego Jana Paderewskiego i Fryderyka Chopina, zaś Edward Linde-Lubaszenko czytał fragmenty książki Jana Baszkiewicza Anatomia bonapartyzmu. 